of gypsy literature. A preliminary edition of this bibliography was issued for revision by European and American scholars in 1909, and the information thus obtained has been used in the present compilation, which includes 4577 entries, accompanied by a good subject index. No attempt has been made to sift the chaff from the wheat, and many books and articles now included have obviously no claim to be regarded as scientific authorities. In a new edition it would be well to define by special type those publications which are really of value. The leading writers on gypsy lore have been fully dealt with-Borrow with 103 entries, Wlislocki, I82, and Bataillard, 41; while the work of English authorities like MacRitchie, Sampson, Thompson, and Winstedt, is adequately recorded.

The bibliography is prepared on scientific principles, and footnotes to the more important articles supply useful information. It is disappointing to note that the Oriental material has been less carefully examined than that of the West. For example, in the case of India, much secondrate material is recorded, while the records of recent ethnographical surveys, and locally published books and pamphlets have often been neglected. It may be hoped that in a new edition the libraries of the India Office, Royal Asiatic Society, the Imperial Library at Calcutta, and other local sources will be more carefully examined.

\section{A Textbook of Domestic Science for High} Schools. By Matilda G. Campbell. Pp. vii + 2 19. (New York: The Macmillan Company, I9I3.) Price 4s. net.

HAD this book been published a few years ago in this country it would probably have been described in its title as a book of "domestic economy." It is concerned chiefly with cookery, which is regarded frankly as an art, and taught as usual by recipes. The treatment is not scientific in the proper sense, and the few chemical formulæ and statements of fact about chemistry introduced will serve only to confuse the student. Under a different title, and with some omissions, we should have here a good book on practical cookery.

The Religious Revolution of To-day. By Prof. J. T. Shotwell. Pp. ix +162 . (Boston and New York: Houghton Mifflin Co., I9I3.) Price I. ro dollars net.

Prof. Shotwell here publishes the William Brewster Clark Memorial lectures he delivered last year at Amherst College. These lectures are in memory of Dr. W. B. Clark, who graduated from Amherst in 1876 , and their object, a foreword to the volume states, is to assist "in throwing light in a genuinely scientific spirit upon the relation of the research, discovery, and thought of the day to individual attitude and social policy." The titles of the lectures are: "Contrasts," "Devolution or Evolution?" "The Problem and the Data," and "The New Régime."

\section{LETTERS TO THE EDITOR.}

[The Editor does not hold himself responsible for opinions expressed by his correspondents. Neither can he undertake to return, or to correspond with the writers of, rejected manuscripts intended for this or any other part of NATURE. No notice is taken of anonymous communications.]

\section{Active Nitrogen.}

A FurTHER paper by Tiede and Domcke has appeared (Berichte, February 7, I9I4) in which it is stated that bomb nitrogen passed over copper moderately heated (to about $400^{\circ} \mathrm{C}$.) is incapable of giving the glow characteristic of active nitrogen. This is held to confirm the previous statement by the same authors relative to nitrogen prepared by heating a metallic azide. In each case the result is attributed to the successful elimination of any trace of oxygen.

We have carefully repeated this new experiment, taking every precaution. All parts of the apparatus were sealed together by fusion. Its lightness was thoroughly tested, both before and after the experiment, and occluded gases were carefully got rid of. The column of copper employed consisted of rolls of the finest gauze (ninety threads to the inch), carefully reduced from the oxidised condition. Its length was $50 \mathrm{~cm}$., and its diameter i $7 \mathrm{~mm}$. The temperature was slowly taken up from I $5^{\circ} \mathrm{C}$. to $480^{\circ} \mathrm{C}$., without any distinct change in the intensity of the glow at any stage. The experiment has been repeated on several occasions before colleagues. A subsequent examination of the copper showed that oxidation had not proceeded for more than $8 \mathrm{~cm}$. We emphatically dissent therefore from Tiede and Domcke's conclusion, in this case, as in the previous one.

The rest of their paper is an attempt to show that some of the characteristic effects can be got with oxygen only, in the entire absence of nitrogen. We must content ourselves here with saying that we do not agree with their observations, but that these would not tell against the existence of active nitrogen, even if they were correct. The conclusive fact is the capacity of the gas to react with, e.g. Kydrocarbons, to form hydrocyanic acid. This they have not attempted to dispute.

We are glad to see that Koenig and Elöd (Berichte, February 2I, I9I4) are in agreement with us that azide-nitrogen gives the glow perfectly well.

H. B. BAKER.

R. J. StRutt.

Imperial College of Science, March 3 .

\section{Remarkable Upper-Air Records at Batavia.}

Two sounding-balloons liberated at Batavia during the present rainy season have met with exceedingly low temperatures, when entering the stratosphere at the usual height of about 17,000 metres (10.6 miles).

On December $4,1^{1}{ }^{1} 3,-90.9^{\circ}$ C. $\left(-131.6^{\circ} \mathrm{F}\right.$.) was registered, and on November $5-91.9^{\circ} \mathrm{C}$. $\left(-133.4^{\circ} \mathrm{F}.\right)$. Though in this last case the clockwork had stopped, the register may be accepted without reservation. I believe this air temperature of $-9 \mathrm{I} \cdot 9^{\circ} \mathrm{C}$. to be the lowest on record.

On December 4 the balloon (weight $2.2 \mathrm{~kg}$.) reached a height of 26,040 metres ( 16.2 miles), and the registering, both in the ascent and in the descent, is to be depended upon, as will be proved below. What is most remarkable in the temperature record is that from 17,000 metres upward an increase from $-91 \cdot 9^{\circ} \mathrm{C}$.

$$
\text { NO. 23I4, VOL. 93] }
$$

